\title{
10 Éves az MTA Pedagógiai AlbizotTságÁNAK TANTÁRgYPEDAGóGIAI-SZAKMÓDSZERTANI ALBIZOTTSÁGA
}

\author{
SZARKA JÚLIA \\ az Eötvös Loránd Tudományegyetem Pedagógiai és Pszichológiai Karának \\ egyetemi docense \\ szarka.julia@gmail.com
}

2001 áprilisában az Albizottság megalakulásának célja Medgyes Péter kezdeményezésével az volt, hogy a tantárgypedagógiák és szakmódszertanok szerepének jelentőségét hangsúlyozó szakmai kör jöjjön létre az Akadémia Pedagógiai Bizottsága keretében. Eredeti - és napjainkig érvényes - terveink szerint a különböző területek képviselöinek részvételével ismerjük és vitatjuk meg „örökérvényü és aktuális" problémáinkat az óvodáktól a doktori iskolák szintjéig. Azóta is törekszünk évente háromszor, általában egy-egy téli, tavaszi és őszi időpontban találkozni, ill. önálló konferenciát szervezni - a lehetőségekhez mérten - évente.

Minden megbeszélésen felmerülnek aktuális problémák, melyben a bolognai folyamat - pedagógusképzés - szakmódszertanok kérdéseire próbálunk válaszokat keresni, egyben a jelen és jövő feladatait is meghatározni.

Az Albizottság elnevezésén megalakulásunk óta folyamatosan és hosszasan vitatkozunk, a kezdetekben felmerültek a „tantárgypedagógia, oktatástechnológia, szakmódszertan, módszertan" kifejezések, melyek egyike sem tudja igazán tükrözni azokat a feladatokat, amelyek a hétköznapok tanulási folyamatában a legnehezebbek közé tartoznak: hogyan keltsük fel és tartsuk fenn az érdeklődést ebben a folyamatban, mit és mennyit tanítsunk és azt milyen módszerrel?!

2009-ben tagságunk döntése szerint Tantárgypedagógiai-szakmódszertani Albizottság lettünk, továbbra is szem előtt tartva Medgyes Péter gondolatait, melyet a mai napig a bizottság mottójának tartunk: „Virágozzék ezer virág a módszertanok területén, de mindig tartsuk szem előtt tanulóink érdekeit!”

Tagságunk elsősorban a felsőoktatás oktatóiból áll össze, egy-egy tantárgypedagógiai, szakmódszertani terület jeles és vállalkozó képviselőiből, de a közoktatás különböző szintjeiből is fogadunk érdeklődő kollegákat. A PhD, ill. DLA minősítések megszerzésének kötelezősége nem könnyíti meg helyzetünket, de továbbra is számítunk a nem minősített, szakterületükön elismert külsős tagok aktivitására.

Jelenleg folyik a tagságunk „megerősítése”, a tagság feltételeinek kialakítása, vállalási nyilatkozatok kitöltése, a honlapunk megújítása és fejlesztése. Megbeszéléseinket továbbra is évi 2-3 alkalommal tartjuk, és egyre inkább az internetes kapcsolattartásra „kényszerülünk”. 
Bizottságunk bővülni, egyben „nyitottabbá” válni szeretne a közoktatás minden szintje felé, próbáljuk a kapcsolatot felvenni más szakbizottságokkal, egyesületekkel. Hosszabb távon kiadványokkal, könyvekkel, gyüjteményekkel is szeretnénk segíteni a pedagógusok munkáját, de ez megint finanszírozási kérdés, amire nincs keret. Időnként a tagság kapcsolatai teszik lehetővé, hogy munkánkat valamennyire dokumentálhassuk, így előző elnökünk, Hegedüs Gábor segítségével a tanácskozások előadásai megjelentek a Projektpedagógiai kiadványokban, ill. az Iskolakultúra folyóiratban.

Fontosabb témáinkat a 10 év alatt - korántsem a teljesség igényével - igyekszünk vázolni a következökben, mintegy történeti elözményeként a jubileumi konferenciához:

- Az elitképzésről, a tudományos diákköri munkáról - Hegedüs Gábor, Poór Zoltán

- A tanárképzés és a módszertanok kapcsolata - Golnhofer Erzsébet

- A nyelvi képzés, a CET bemutatása - Major Éva

- Modernizáció és programfejlesztés - Arató László és Nahalka István

- Az új közoktatási törvény és az OM stratégiája - Sípos János

- A CSEFT-röl: felsőoktatás és integráció különböző modelljei - Hunyady György

- A tantárgypedagógia helye a tanárképzés reformjában - Katona András

- Az újabb PISA felmérések tanulságai - Vári Péter

- Az ÓNK és a szakmódszertanok kapcsolata - Radnóti Katalin, Katona András

- IKT az oktatásban - Füvesi István

- Művészeti-zenei nevelés és a paradigmaváltás - Györgyiné Koncz Judit, Szarka Júlia

- A 2009. szeptemberi országos fizika és kémia felmérésekről - Radnóti Katalin

- Történeti oktatás, tankönyvügy, tankönyvrevízió - Albert Gábor

- A nyelvpedagógia mint tantárgypedagógia tanulságai - Bárdos Jenö

- „Kompetencia a harmadikon, azaz a kompetencia-orientált kompetenciaalapú pedagógusképzés és az abban oktatók releváns kompetenciái” - Poór Zoltán

Önálló konferenciáink szervezésével is próbáltuk az Albizottság és a szakmódszertanok jelentőségét igazolni:

- 2004. szeptember 24. Szakmódszertani tanácskozás

- 2006. április 7. „Képességfejlesztés és módszertan” c. tanácskozás

- 2007. szeptember 21. „Hogyan tovább szakmódszertan” c. tanácskozás

- 2009. június 5. „Múlt-jelen-jövő a szakmódszertanok tükrében” c. tanácskozás

- 2010. szeptember 3. Tanévnyitó Tantárgypedagógiai Tanácskozás 
2011. június 3-án a 10 éves jubileum jegyében rendezhettünk meg ismét konferenciánkat. A tanácskozáson az Albizottság korábbi és jelenlegi tagjai mutatták be újabb témáikat, kutatásaikat, így a következőkben bemutatott rövid összefoglalások az elhangzás sorrendjében jelzik a kollegáinkat érdeklő és érintő aktuális problémákat is.

Medgyes Péter Aranykor - nyelvoktatásunk 20 éve: 1989-2009 címü előadásában kiemelte, hogy az elmúlt két évtizedet sokan csalódások sorozataként élték meg. Egyvalami azonban bizonyosan kivételt képez: az idegennyelv-oktatás egyértelmű sikertörténetnek bizonyult. Noha európai összehasonlításban mindmáig a futottak-még kategóriába tartozunk, a magyar lakosság idegennyelv-tudása ugrásszerüen javult 1989 óta. Előadásában azt vizsgálta meg az előadó, hogy mennyiben köszönhető ez a fejlödés a nyelvoktatási rendszerünkben, módszereinkben bekövetkezett változásoknak. Sorra bemutatta azokat a programokat, projekteket és egyéb történéseket, amelyek hozzájárultak e felfelé ívelő trend kialakulásához.

Radnóti Katalin elöadásában hangsúlyozta, hogy a természettudományi tantárgyak meglehetősen nehéz helyzetben vannak napjaink közoktatásában. A rendszerváltást követő években fokozatosan csökkentek az óraszámok, vagyis napjaink technicizált világában, mely elsősorban a természettudományokban tett különböző felfedezéseknek köszönheti létét, az iskolában fokozatosan szorul vissza. A tanulók körében sem népszerúek a természettudományi tantárgyak, pedig szerepük alapvető fontosságú a természettudományos, illetve mérnöki szakok számára. A tanárképzési szakok pedig szinte kiürültek, különösen nagyon kevesen választják a fizika és a kémia tanári szakokat. Az előadásban ezt a problémát járta körül Radnóti Katalin.

Füvesi István A távvezérelt interaktív tábláig vezető út címü előadásában felhívta a figyelmet arra, hogy az utóbbi évtizedben felgyorsult a szaktárgyi oktatást támogató eszközrendszerek fejlesztése, s megjelenése különösen a közoktatás területén. Ugyancsak nagy számban jelennek meg a fogyatékkal élők oktatását támogató infokommunikációs eszközök is, melyek az esélyegyenlőség megteremtésének irányába hatnak. Ezek módszertanilag is helyes használatára a tanárokat fel kellene készíteni, s ennek elsődleges színtere a felsőoktatás kellene legyen.

Nagy Lászlóné A természettudomány-tanítás kutatásának helyzete címü elöadásában tisztázta a természettudományos nevelés mint önálló, interdiszciplináris kutatási terület szükebb és tágabb értelmezését, ismertette főbb kutatási kérdéseit, továbbá rámutatott a kutatási eredmények hasznosításának lehetőségeire a természettudományos tárgyak tartalmi és módszertani megújításában és a természettudományos tanárképzés reformjában.

Bencéné Fekete Andrea az interaktív idegennyelv-elsajátítás témakörével foglalkozott. Néhány évtizeddel ezelőtt még szinte lehetetlennek tartották, hogy iskoláskor előtt a gyermekek idegen nyelvet tanuljanak. A tudósok vitái, a nyelvészek és neurológusok kutatásai egyre inkább támogatják a nyelvtanároknak azt a törek- 
vését, hogy minél előbb lehetőséget kell biztosítani anyanyelv mellett más nyelv megismerésére is. A 2009/2010-es tanévben indult kutatás a kaposvári Pumukli óvodában. Az idegennyelvi foglalkozás tartalma kapcsolódik az anyanyelven folyó óvodai tevékenységekhez, leginkább a játékhoz. Az elsődleges cél a kísérlet során megvalósult, mivel a gyermekekben pozitív attitüd alakult ki a német nyelv tanulása iránt, és a nyelvtudásuk mellett más képességeik, készségeik is fejlődtek. A korai nyelvtanulás a későbbiekben is a hasznukra válik, remélhetőleg idősebb korban is könnyebben sajátítanak majd el további nyelveket, mint azonos képességü társaik, akik nem tanulnak a kritikus periódus elött idegen nyelvet.

Albert B. Gábor Taníthatunk-e historiográfiát kisiskolásoknak? címü előadásában saját kutatását mutatta be. Az előadó több éve folytatott osztálytermi akciókutatást a budatétényi Rózsakerti Általános Iskolában. A historiográfiai történelemszemlélet programja a Zsolnai József által megindított tudománypedagógiai akciókutatás részeként arra keresi a választ, miként lehet a historiográfiai gondolkodás alapjait már kisiskolás korban kialakítani, hogyan lehet nagyobb teret biztosítani a történelemtanításban és tankönyvekben. Egy-egy történelmi esemény, személy historiográfiai feldolgozása, megítélésének változástörténete a gyermek életében játszott szerep relevanciája szempontjából ugyanis hasznos: segíti a gyermek ítéletalkotó képességének kialakítását, az egységben, rendszerben, folyamatban látás feltételeit is, és a témák bemutatása élményt, katarzist is biztosítanak. Érdekes példa a Guszev kísérletet, ahol egy bemutató órán az ezüst Kossuth-díjas tankönyv pozitív példaként említette meg az 1848-49-es szabadságharc orosz „hősét” Guszevet, aki a valóságban nem létező, kitalált történelmi személy volt. A tankönyvi történelemhamisítás közös leleplezése, mely nagyfokú megrökönyödést váltott ki a tanulókban, alkalmat kínált a személyiségfejlesztésre, a felelősség-etika kérdéseinek tisztázására is. Kitért Albert B. Gábor a historiográfiának a történelem tantárgy keresztmetszetében történő bemutatására is. A történelem hiteles közvetítése stabil tantárgytörténeti háttértudással is rendelkező pedagógust feltételez. A tantárgytörténeti háttértudás elsajátítását a historiográfia, a historiográfiai gondolkodás nagymértékben elősegíti, ill. mint megközelítési mód segíti a neveléstörténeti kutatásokat is.

Györgyiné Koncz Judit és Szarka Júlia Hogyan tovább zenepedagógia? címmel tartották meg előadásukat. Mủvészetekkel/zenével foglalkozni nem felesleges időtöltés, hanem a társadalom számára gazdaságilag is hasznos stúdium. Ezt egyre többször kellene bizonyítani: akár a hungaricumnak nyilvánított Kodály-módszer újraélesztésével, a zenei megnyilatkozásoktól, énektől-mozgástól való félelem leküzd(et)ésével, pedagógus-továbbképzések megújulási szándékával. Tovább kell menni a megfelelő utakon: akár a születés előtti zenei nevelés, a baba-mama/papa! programok terjesztésével, az intézményi szinteken a zenei tagozat megőrzésével. De mindenképpen a mindennapos-tudatos zenei neveléssel, amelybe bele kell férjen a hagyományaink, értékeink megőrzése mellett az igényes megújulás szándéka. 
Steklács János az elmúlt évek olvasáskutatási projektjeinek eredményeit mutatta be. Az előadás azokkal a tendenciákkal foglalkozott, amelyek az olvasás, szövegértés területén radikálisan átalakították a tudományos diskurzus hagyományos kérdéseit, gondolkodásmódját. Arra kereste a választ, hogy a társadalmi elvárásoknak, a korszerủ szemléletnek megfelelően melyek lennének a szükséges lépések, hogy az iskolarendszeren belül az olvasástanítás meg tudjon felelni a társadalmi követelményeknek, felruházva az egyént olyan szintü írásbeli kommunikációs képességekkel, kompetenciákkal, amelyek segítik boldogulását, beilleszkedését, érvényesülését. A helyzet elemzése után kitért az előadó a ma meghatározó kutatásokra, definíciókra, eredményekre. Ezt követően az előadás betekintést nyújtott a kecskeméti mühelyben folyó munkáról, nemzetközi együttmüködésekröl, a közeljövő kutatási programjáról, terveinkröl, bemutatva azt a módszert is, amely segítségével beépítik tapasztalataikat a tanítók képzésébe, továbbképzésébe.

Remélhetőleg napjaink számos társadalmi-oktatási kérdése és problémája mellett a tantárgypedagógiák és szakmódszertanok szerepe továbbra is fontos marad, lehetősége lesz a kollegáknak további kutatásokra. 